\title{
THE ENFORCEMENT OF FOREIGN DECREES FOR ALMMONY
}

\author{
Albert C. Jacobs*
}

In a court of competent jurisdiction of a state in which a husband and wife are resident, the wife successfully sues the husband for a divorce or separation and alimony. The decree awards her alimony for the support of herself and children, if there be any, either in the form of a lump sum or installment payments. To avoid the sanction of this court, the husband, leaving no appreciable assets behind him, flees to a second state. The wife, in dire need, and no longer possessing an effective remedy in the state where the divorce was granted, attempts in the second state to enforce the decree providing for support. Or the wife, having obtained a decree for divorce or separation and alimony in a state where she was then resident, returns to the state of her former residence and seeks to obtain payments under that decree.

These patterns are typical; the cases presenting questions as to the enforcement of foreign ${ }^{1}$ decrees of alimony very generally follow one of these fact situations. For convenience of reference, in the discussion which follows husband and wife will be designated by the symbols $H$ and $W$, respectively. The state which is the forum of the divorce action wherein alimony is awarded will be designated as $F-I$; the second state, the forum of the suit brought on the alimony decree, as $F-2$.

What remedies are available to $W$ in $F-2$ ? Must the courts thereof give "full faith and credit" to the alimony decree of the $F-I$ tribunal? If so, what does this mean? Is it material whether the $F-I$ decree is for permanent or temporary alimony, whether it provides for a lump sum or for installment payments, whether it is subject to modification by the $F-I$ court? Can $W$ sue in $F_{-2}$ for the lump sum or for the payments which have accrued and are in arrears? Can she do anything to secure the payment of the future installments as they come due? What is the nature of her remedy in $F-2$ ? Must she sue at law, relying upon the attendant legal execution, or can she proceed in equity? If equitable relief is open to her in $F-2$, is she entitled to the remedies which would have been available to her had she obtained a local alimony

-A.B., 192x, University of Michigan; B.A., 1923, B.C.L., 1924, M.A., 1927, Oxford. Professor of Law, Columbia University. Co-author of $A$ Research in Family Law (1930); author of Cases and Matcrials on Landlord and Tenant (1932); Cases and Other Materials on Domestic Relations (2d Ed. 1939); and of contributions to legal periodicals in the field of family law.

1"The term "foreign" is applied, as the antonym of "domestic," to sister states of the United States as well as to foreign nations. 
decree there? Or can she take advantage of the remedies which would have been open to her in $F-I$ ?

The problem of the remedies available for the enforcement in $F-2$ of a decree for alimony rendered in $F-r$ has become increasingly important. Divorce rates have risen to such an extent in recent years that they have become the highest in our history. 2I8,000 decrees were issued in I935, probably more in the succeeding years. ${ }^{2}$ When a husband has been ordered to pay money for the support of a woman no longer his wife or from whom he is legally separated, it is not at all strange that he should indicate an inclination not to comply with the decree. The arranged, the friendly divorce, it is true, is typical of our times. ${ }^{3}$ In the amicable divorce or separation economic matters are generally arranged out of court. It is in the real contest, where parties are not on friendly terms, that most alimony awards are made. ${ }^{4}$ With the evolution of faster and more accessible means of transportation, with the development of the automobile, the streamliner and the airliner, husbands against whom alimony decrees have been rendered in $F-I$ find flight from the state to escape the enforcement thereof more and more easy. Problems of real social import are thereby raised. It is just as much a need of society and justice that alimony be paid in $F_{-2}$ as it was in $F-L .^{5}$

The law concerning the enforcement of a foreign alimony judgment is still in an evolutionary stage. At one time there was considerable hesitation as to the extraterritorial effect of an $F_{-I}$ alimony decree. ${ }^{6}$ In Battey, Executor v. Holbrook, ${ }^{7}$ it was said by way of dicta, that "upon a decree for alimony, it may be well to remark by way of caution, we suppose no action will lie in another jurisdiction."

A decree for alimony is an order of a competent court, usually incidental to a suit for a divorce a vinculo or a mensa et thoro, ordering the husband to pay a certain amount, either in a lump sum or periodically for the support of the wife and children, if there be any. ${ }^{8}$ It is generally an obligation of the same nature as the marital duty to support. Thus it is an obligation in the enforcement of which the state has a paramount public interest-the wife and children must not become public charges and derelicts. For this reason there attaches to an alimony decree a public policy in securing to the wife the performance of this duty to support. The remedies for enforcement are more effective than those available in the case of an ordinary law

\footnotetext{
2 The last report of the United States Department of Commerce, Bureau of Census, on Marriage and Divorce, was issued in 1934 and covered the year 1932 . For subsequent statistics, see Stouffer and Spencer, Marriage and Divorce in Recent Years (Nov. 1936) ANNals, 56-69.

${ }^{3}$ Collusive and Consent Divorce and the New York Anomaly (1936) 36 CoL. L. Rev. xI2I; Jacobs, Attack on Decrees of Divorce (1936) 36 Mrck. L. Rev. 749; Sayre, Divorce by Judicial Consent (1933) x 8 IOWA L. REv. 493.

According to Cahen, Statistical Analysis of American Divorce (1932), nine pet cent of the divorce petitions now request alimony, and it is granted in six per cent.

"See Ostrander v. Ostrander, I90 Minn. 547, 550, 252 N. W. 449 (1934).

'See Barber v. Barber, 2 Pin. 297, I Chand. 280 (Wis. I849); Battey, Ex'r. v. Holbrook, Ir Gray 2r2, 213 (Mass. 1858 ).

${ }^{7}$ Supra note 6.

${ }^{8}$ See 2 Vernier, Aarerican Family Laws (1932) 259-325, 45I-462; Munson, Some Aspects of the Nature of Permanent Alimony (I916) 16 CoL. L. REv. 217.
} 
judgment or money decree. ${ }^{9}$ A local alimony order is generally accorded the full scope of equitable enforcement. In addition to the ordinary means available for the collection of money judgments, the injunction, ${ }^{10}$ sequestration of the husband's property, ${ }^{11}$ receivership, ${ }^{12}$ the writ of ne exeat, ${ }^{13}$ and contempt proceedings ${ }^{14}$ are often open to the wife. In other ways as well, because of the public import involved, the law has given special protection to an alimony judgment. It survives the bankruptcy of the husband, ${ }^{15}$ it generally prevails over the exemption laws; ${ }^{16}$ by the weight of authority it is exempt from garnishment, except for debts contracted for necessaries subsequent to the divorce; ${ }^{17}$ imprisonment for failure to pay alimony does not violate the constitutional provisions against imprisonment for debt. ${ }^{18}$ These will suffice to illustrate the important point that a decree for alimony is sui generis.

In the discussion which follows it will be assumed that the $F_{-I}$ court rendering the alimony judgment has jurisdiction over the subject matter and personal jurisdiction over the parties. ${ }^{18}$ It will further be assumed that the divorce or judicial separation, where such is involved, is one which will be recognized in $F-2$ either under the full faith and credit clause, on the ground of comity, or because of estoppel or some analogous principle. ${ }^{20}$

The Constitution of the United States ${ }^{21}$ and the statutes enacted thereunder ${ }^{22}$ enjoin the courts of the several states to give "full faith and credit" to the judicial proceedings of every other state. It is elementary that this calls for more than the

The statutory material on enforcement and security provisions is collected in 2 Vernier, Amerrcan Fandly Laws 290-303. See Mass. Gen. Laws (1932) c. 208, 5512-14, 25, 36; Mich. Comp. Laws (I929) $\$ 512742$, I2743, I2747, 12770, I2780, I3910; N. Y. Civ. PRAc. Act. \$\$II7I, II7Ia, II72.

${ }^{10}$ In re White, II3 Cal. 282, 45 Pac. 323 (1896).

${ }_{11}$ Castell v. Castell, 38 Ark. 477 (1882); Swallow v. Swallow, 84 N. J. Eq. 109, 92 Atl. 872 (1915).

${ }^{12}$ Stallings v. Stallings, 127 Ga. 464,56 S. E. 469 (1907).

${ }^{13}$ Boucicault v. Boucicault, 21 Hun. 43 I (N. Y. I880).

14 Foster v. Foster, 130 Mass. 189 (1880).

${ }^{28}$ II U. S. C. \$35; Audubon v. Shufeldt, I8I U. S. 575 (I90r).

${ }^{10}$ Szymanski v. Szymanski, 188 Iowa $93 \mathrm{I}, 176$ N. W. 806 (I920); Fowler v. Fowler, 6r Okla. 280, I6r Pac. 227 (Igr8).

${ }^{27}$ See Harper, Garnishment for Alimony (1928) I3 Iows L. REv. 164.

${ }^{18}$ Bushman v. Bushman, 157 Md. r66, I45 Atl. 488 (1929).

${ }^{10} 2$ Beale, Conflict of Laws (1935) 1435-1436: "Since this decree (for alimony) is in its effect a mere decree for the payment of money by the respondent, it is clearly a decree in personam and not in rem and in order to support it there must therefore be personal jurisdiction over the respondent. If, as often happens, the respondent in the divorce case is served only by publication, being a non-resident, it is not possible to render a valid decree against him for alimony.

"When, however, the respondent is before the court for any reason, the court, having personal jurisdiction over him, may render a decree. This happens if the respondent appears either in the original action or in a later proceeding to dispute the allowance of alimony; if he is served with process either originally; or before the alimony is decreed; if he is a respondent in a successful cross libel and therefore came into court with the original complaint; or if he is domiciled within the state and is required in accordance with the law of the state to come into court."

${ }^{20}$ See Jacobs, supra note 3 .

${ }^{21}$ Art. IV, \$I: "Full faith and credit shall be given in each state to the public acts, records, and judicial proceedings of every other state. And the Congress may by general laws preseribe the manner in which such acts, records and proceedings shall be proved, and the effect thereof."

${ }_{22} 28$ U. S. C. $\$ 688$ : "And the said records and judicial proceedings, so authenticated, shall have such full faith and credit given to them, in every court within the United States as they have by law or usage in the courts of the state from which they are taken." 
mere recognition of the $F_{-I}$ judicial proceedings. The judgment is to be enforced; it must be made effective so that execution can issue thereon in $F-2$. Just a hundred years ago the Supreme Court of the United States said: ${ }^{23}$

"By the law of the 26 th day of May, I790, the judgment is made a debt of record, not examinable upon its merits; but it does not carry with it, into another state, the efficacy of a judgment upon property or persons, to be enforced by execution. To give it the force of a judgment in another state, it must be made a judgment there, and can only be executed in the latter as its laws permit."

A foreign judgment for a sum of money is a debt of record upon which an action can be maintained. It is not enforceable simply by issuing execution thereon or by any other remedy available to judgment creditors. ${ }^{24}$

"No action will lie," however, "in another state on a judgment which is not final and conclusive in a state where it was rendered." 25

This is fundamental and underlies the law dealing with the extraterritorial enforcement of money judgments. In the case of Pennington $v$. Gibson, ${ }^{26} \mathrm{Mr}$. Justice Daniel said:

"We lay it down, therefore, as the general rule, that in every instance in which an action of debt can be maintained upon a judgment at law for a sum of money awarded by such judgment, the like action can be maintained upon a decree in equity which is for an ascertained and specific amount and nothing more. . .."27

At one time there was considerable doubt about this proposition. ${ }^{28}$ But it is now fundamental that if the $F_{-I}$ decree is final and conclusive, be it legal or equitable, an action can be maintained thereon in $F-2 .^{29}$

So much for money judgments in general. A decree for alimony, whether calling for a lump sum or periodic payments, is generally not subject to alteration in the absence of express power to the contrary reserved in the decree itself or provided for by express statute. ${ }^{30}$ An alimony judgment not subject to modification would seem

${ }^{28}$ M'Elmoyle v. Cohen, I3 Pet. 312, 325 (U. S. I839) per Wayne, J.

24 Restatement, Conflict of Laws (1934) $\$ 433$.

Rohden v. Rohden, II9 Misc. 624, 625, I98 N. Y. Supp. I6 (1922): "Judgments and orders of other states have no extraterritorial force as mandates." Per McAvoy, J. Accord: Hardy v. Hardy, 136 Misc. 759,240 N. Y. Supp. 826 (I 930 ).

25 2 Beale, Conflict of Laws r390. See also Restatement, Conflict of Laws (I934) $\$ \$ 434,435$. \$435: "A valid foreign judgment for the payment of money which by the law of the state in which it was rendered is not a final judicial determination of the right to payment will not be enforced."

${ }^{36}$ I6 How. 65, 77 (U. S. 1853 ).

${ }^{37}$ See Wagner v. Wagner, 26 R. I. 27, 28, 57 Atl. 1058 (I904).

${ }^{38}$ See Barber v. Barber, supra note 6.

${ }^{20}$ See 2 Beale, Conflict of Laws I38x; Restatement, Conflict of Laws (1934) $\$ 434$, comment $c$.

${ }^{30}$ Mayer v. Mayer, 154 Mich. 386, 390, II7 N. W. 890 (1908): "We think the authorities generally sustain the proposition that a decree for alimony in a divorce $a$ vinculo made without reserve, although payable in installments, is final and cannot be challenged after enrollment of the decree."

2 Vernier, American Family Laws 274-275: "If alimony in absolute divorce is a substitute for the wife's right to support by her husband, it would seem that it should be subject to change according to changes in the needs of the wife or in the ability and proper obligations of the husband, just as the right to support would change if the marriage had continued. This seems to be the rule of the ecclesiastical courts in limited divorce cases, and of the courts of a few American jurisdictions in cases of absolute 
to have the finality of an ordinary money judgment. It is common practice, however, for courts to reserve in the decree the power to vary, modify or annul it, and statutes conferring such power exist in many states. ${ }^{31}$ Such being the case, has the alimony decree that final and conclusive character upon which enforcement in $F-2$ is conditioned? Does it fall within the pattern providing for the enforcement of money judgments?

Where the decree of $F_{-I}$ calls for the payment of alimony in a lump sum, and there is no power statutory or otherwise to annul, vary or modify it, we are, it seems, dealing with something like an ordinary money judgment. This situation presents no difficulty so far as legal enforcement in $F_{-2}$ is concerned. And, as would be expected, courts have given full faith and credit to such a decree. ${ }^{32}$

If $F_{-I}$ has no statute authorizing modification or annulment and the court has reserved no such power unto itself, a decree calling for periodic payments would seem to be final and conclusive, at least as to the accrued and unpaid installments. They would seem to constitute a debt, and since not subject to modification or cancellation, would be final and conclusive and entitled to recognition in $F-2$. But suppose that by statute or express reservation in the decree the court has the power to vary, modify or annul? Is it material whether this power extends to accrued and unpaid installments or merely to those not yet due? To answer these questions it is necessary to turn to an analysis of the leading cases.

The famous case of Barber $v$. Barber, ${ }^{33}$ in the Supreme Court of the United States, is the starting point of all discussion in this field. In 1847 , the Court of Chancery of New York had granted Huldah Parker a divorce a mensa et thoro from her husband and had directed the latter to pay her alimony in quarterly installments. Although the separation was decreed to be forever, the power to modify was reserved by a provision that the parties might at any time thereafter, by their joint petition, apply to the court to have the decree modified or discharged. It was provided that the unpaid installments of alimony should bear interest "and that execution might issue therefor toties quoties." The husband failed to pay any of the alimony and

divorce. The prevailing rule in our civil courts appears to be that the court cannot alter the decree after it has been made, unless power to do so was reserved therein or unless there is statutory authority to do so. Nevertheless, it is submitted that such authority should not be necessary. The majority rule scems to proceed upon the theory that the decree is res judicata as to alimony. Admittedly this is correct as to the state of facts existing when the decree was made."

31 Vernier, AMERICAN FAMILY LAWS 275, points out that such statutes exist in 3I of the 5I American jurisdictions. See Cax. Crv. Code (Deering, I937), §139; Mass. Gen. Laws (1932), c. 208, §37; N. Y. Crv. Prac. Act, $\$ \$ 1155,1159$, r170.

${ }^{32}$ Dow v. Blake, 148 IIl. $76,87,35$ N. E. $76 x$ ( 7893 ): The plaintiff wife successfully maintained an action of debt upon a judgment in her favor in Wisconsin for $\$ 31,000$ as alimony. "We see no reason why a final decree, which directs the payment of a specific sum of money, should not have the same force and effect as a judgment at law; and it has not been shown that it does not have such force and effect in the State of Wisconsin. Where such a final decree is rendered by a court of competent jurisdiction in one State, the Constitution of the United States requires that full faith and credit be given to it in every other State. It makes no difference, so far as the duty of the courts in another State to enforce it is concerned, that the specific sum required to be paid by such a final decree is for alimony."

See also 2 Beale, Conflict of Laws 1392.

${ }^{38} 2$ I How. 582 (U. S. I858). 
removed to Wisconsin where he procured an ex parte absolute divorce. ${ }^{34}$ Subsequently an action was brought by Mrs. Barber upon the common law side of the Federal District Court in Wisconsin to recover the arrears of alimony. ${ }^{35}$ Relief was denied, however, "for the reason that the remedy for the recovery of alimony was in the court of chancery and not at law."36 A suit to recover the overdue alimony was then commenced by the wife's next friend on the equity side of the court. The defendant husband demurred on the ground of lack of jurisdiction of the court of equity in that the plaintiff wife could not acquire a domicil separate and apart from his, since the marriage status was not dissolved by a judicial separation, and there was, therefore, no diversity of citizenship; that relief could only be had in the Court of Chancery of New York; and that it did not appear that the wife had exhausted her remedies in New York. The demurrer was overruled and the defendant then answered admitting the New York decree and not raising any question as to its finality. ${ }^{37}$ From a decree for the plaintiff, the defendant appealed to the Supreme Court of the United States. The issue was thus stated by Mr. Justice Wayne:

"Whether a wife divorced a mensa et thoro can acquire another domiciliation in a state of this Union different from that of her husband, to entitle her, by her next friend, to sue him in a court of the United States having equitable jurisdiction, to recover from him alimony due, and which he refuses to make any arrangement to pay; and whether a court of equity is not a proper tribunal for a remedy in such a case." 38

The court devoting the greater part of its opinion to the resolution of the real issue in the case-whether the wife could set up a domicil separate and apart from her husband's-concluded that the wife was entitled to sue. No point was made by counsel as to the effect of the New York alimony decree. ${ }^{39}$ The court, however, dealt with this situation:

"The decree ... . is a judgment of record, and will be received as such by other courts. And such a judgment or decree, rendered in any state of the United States, the court having jurisdiction, will be carried to judgment in any other state, to have there the same binding force that it has in the state in which it was originally given. For such a purpose, both the equity courts of the United States and the same courts of the states have jurisdiction."40

\footnotetext{
sc "It is not necessary for us to pass any opinion upon the legality of the decree, or upon its operation there or elsewhere to dissolve the vinculum of the marriage." 21 How. 582, 588 (U. S. 1858), per Wayne, J.

${ }^{35}$ Barber v. Barber, supra note 6.

${ }_{\text {so }}$ The husband had demurred on the ground that the wife's remedy was in equity. The sustaining of the demurrer was affirmed. "The decree for alimony is a specific one for the support of the wife, and in its nature distinct and temporary. It may be increased as the necessities of the case may require, and the ability of the husband permit, or it may be diminished or dissolved. Hence it cannot be regarded as a decree absolute for the payment of a sum certain, nor has it the force and effect of a judgment at law. It belongs to that numerous class of decrees which, from their very nature, cannot be enforced in any other than a court of chancery, where one exists." Per Larrabee, J., Barber v. Barber, 2 Pin. at 300, I Chand. at 284 (Wis. 1849 ).

See also dicta to the same effect in Battey, Ex'r v. Holbrook, supra note 6.

37 The husband claimed that by the Wisconsin divorce his wife became a feme sole, and could not sue by her next friend, and that her remedy was in a court of law.

${ }^{39} 2$ How. 582,584 (U. S. 1858 ).

${ }^{a}$ It did not appear whether the New York court had power to modify the decree as to accrued installments.

${ }^{10} 2$ I How. 582, $59 x$ (U. S. I858), per Wayne, J.
} 
Mr. Justice Wayne continued:

"When that has been done, it becomes a judicial debt of record against the husband, which may be enforced by execution or attachment against his person, issuing from the court which gave the decree; and when that cannot be done on account of the husband having left or fled from that jurisdiction to another, where the process of that court cannot reach him, the wife, by her next friend, may sue him, wherever he may be found or where he shall have acquired a new domicil, for the purpose of recovering the alimony due to her, or to carry the decree into judgment there with the same effect that it has in the state in which the decree was given. Alimony decreed to a wife in a divorce of separation from bed and board, is as much a debt of record, until the decree has been recalled, as any other judgment for money is." 41

Due to the way in which the matter was presented and in which the issues were formulated, these statements were undoubtedly mere dicta. The decision was that the trial court did not err in giving effect to the New York decree. But by implication the court indicated that an $F-I$ alimony decree, payable in installments, is a debt of record ${ }^{42}$ and as such is entitled to full faith and credit in $F-2$, until the decree is recalled, even though it is subject to recall. As to the accrued installments it must be enforced in $F-2 .{ }^{43}$

The statements of the Supreme Court were followed in the cases which arose. They were stated over and over again, becoming law in the state courts without qualification. ${ }^{44}$

Then came another decision of the Supreme Court of the United States-the much discussed and oft-misunderstood case of Lynde v. Lynde. ${ }^{45}$ The plaintiff wife sued in New York to enforce a claim for alimony which had been obtained against the defendant husband in a court of chancery in New Jersey. The New Jersey decree adjudged that the plaintiff recover the sum of $\$ 7,840$ as back alimony [the amount decreed to be due and payable], counsel fees of $\$ \mathrm{r}, 000$; and that the defendant pay permanent alimony of $\$ 80$ a week from the date of the decree, authorizing the issue of execution therefor, declaring these sums to be liens upon the defendant's real

${ }^{42} 2$ I How. 582, 595 (U. S. I858).

"The phrase "debt of record" originated at an early date to enable a person who had been awarded a money equity decree to instizute an action at law. Post v. Neafie, 3 Caines 22 (N. Y. 1805). Sce Cook, The Powers of Courts of Equity (I915) I5 CoL. L. REv. 106, 240; Barbour, The Extra-Territorial Effect of the Equitable Decree (19r9) 17 Mrcr. L. Rev. 527. The expression was adopted for its convenience in signifying that a final decree was such a judgment as would be capable of supporting an action of debt. See (1937) 85 U. of PA. L. REv. 726, 728; Pennington v. Gibson, supra note 23; McElroy v. McElroy, 208 Mass. $458,464,94$ N. E. 696,699 (I9II).

${ }^{4}$ See, however, the dissent of Daniel, J.: "This allowance is not in the nature of an absolute debt. It is not unconditional, but always dependent upon the personal merits and conduct of the vife-merits and conduct which must exist and continue, in order to constitute a valid claim to such an allowance. This allowance might unquestionably be forfeited upon proof of criminality or misconduct of the wife, who could not be permitted to enforce the payment of that to which it should be shown she had lost all just claim; and this inhibition, it is presumed, might embrace as well a portion of that allowance at any time in arrears, as its demand in future." 21 How. 582,603 (U. S. 1858 ).

"Dow v. Blake, 148 Ill. 76, 35 N. E. 76I (1893); Allen v. Allen, 100 Mass. 373 (1868); Brisbane v. Dodson, 50 Mo. App. I7o (1892); Bullock v. Bullock, 57 N. J. L. 508, 3 1 Atl. 1024 (1895); Anonymous, I2 Abb. N. C. 160 (N. Y. I800); Wood v. Wood, 7 Mise. 579, 28 N. Y. C. 154 (1894); Trowbridge V. Spinning, 23 Wash. 48, 62 Pac. I25 (1900).

${ }^{45}$ Lynde v. Lynde, 181 U. S. 183 (1901). 
estate, requiring him to give security for the payment of such sums, and providing for sequestration and receivership in case of the defendant's failure to make the prescribed payments or to furnish the prescribed security.

The Supreme Court of New York decreed that the plaintiff was entitled to a judgment against the defendant, first, for the amount of alimony, counsel fee and costs due or incurred under the New Jersey decree; second, for the amount of alimony accrued since the date of the New Jersey decree; third, that he pay to her $\$ 80$ a week from the date of the decision, as and for permanent alimony; and lastly, that he give a bond in the sum of \$100,000, to secure the payment of the several sums specified and that, upon his failure to comply with the provisions of the decision, a receiver might be appointed by the Court of Chancery of New Jersey.

The Appellate Division, ${ }^{46}$ upon the defendant's appeal, modified the judgment, so that the plaintiff recovered of the defendant the sum of $\$ 8,840$, representing the amount of back alimony awarded by the New Jersey decree plus the $\$$ r,ooo counsel fee. Both parties thereupon appealed to the Court of Appeals which unanimously affirmed the judgment as above modified. ${ }^{47}$ In the words of Gray, J.:

"As a debt of record against the defendant the courts of this state should give it full credit and effect; but as to its other provisions for future alimony and for equitable remedies to enforce compliance, I do not think we should say that it falls within the rule of the Federal Constitution. I do not think that the courts of this state should give effect to the decree by enforcing any of the collateral remedies, which the prevailing party may be entitled to in New Jersey and which the subsequent order gave to her.

"So far as it made provision for the payment of alimony in the future, it remained subject to the discretion of the chancellor and lacked conclusiveness of character. The chancellor's action was not final on the subject. ... The provision of the Federal Constitution, which requires that full faith and credit shall be given to the judicial proceedings of another state, in my opinion, should be deemed to relate to judgments, or decrees, which are not only conclusive in the jurisdiction where rendered, but which are final in their nature. If they, once and for all, establish a debt, or other obligation, against a party, the record is available in other jurisdictions as a foundation for a judgment there." 48

In the Supreme Court of the United States, in an opinion notable for its brevity, the decision of the Court of Appeals was affirmed. ${ }^{49}$ Mr. Justice Gray said:

"The decree for the payment of $\$ 8,840$ was for a fixed sum already due, and the judgment of the court below was properly restricted to that. The provision for the payment of alimony in the future was subject to the discretion of the Court of Chancery of New Jersey, which might at any time alter it, and was not a final judgment for a fixed sum. The provisions for bond, sequestration, receiver, and injunction, being in the nature of execution, and not of judgment, could have no extraterritorial operation; but the action of the courts of New York in these respects depended on the local statutes and practice of the State, and involved no Federal question." 50

\footnotetext{
${ }^{40}$ Lynde v. Lynde, 4I App. Div. 280, 58 N. Y. Supp. 567 (I899).

${ }^{47}$ Lynde v. Lynde, 162 N. Y. 405,56 N. E. 979 (1900).

${ }^{48}$ Id. at $417-418,56$ N. E. 979.

${ }^{60}$ Lynde v. Lynde, I8I U. S. 183 (Igor). $\quad{ }^{50} I d$. at 187.
} 
It is worthy of note that the Supreme Court did not cite nor refer to Barber $v$. Barber. ${ }^{51}$ A limitation, however, was placed upon that case. Where the $F-I$ alimony decree was subject to alteration, modification or annulment, it was not final, and, therefore, not within the full faith and credit clause. In such a situation the wife should first have obtained a decree from the $F_{-I}$ court adjudging the installments accrued and unpaid. On such a decree suit should then be brought in F-2.52

The state courts were thrown into confusion as to the effect of this case upon the statements of Mr. Justice Wayne in Barber v. Barber. Some tribunals clearly took the position that Barber v. Barber, at least in so far as it was inconsistent with Lynde $v$. Lynde, was overruled by the latter decision. ${ }^{53}$ If the installments were subject to alteration or annulment, only the sums due and owing at the time of the $F-r$ decree were entitled to full faith and credit. This was so even though there had been no alteration of the installments which had accrued since the $F_{-I}$ decree. Other courts held that the burden was on the plaintiff in $F-2$ to allege and prove the finality of the F-I decree. ${ }^{54}$ In Hunt v. Monroe, 55 the court said: "It seems to us the safer rule is to require proof of the laws of a sister state in this regard." Some courts, in spite of the Lynde case, assumed in the absence of express proof to the contrary that the $F_{-I}$ decree was final in regard to accrued and unpaid installments. In Wagner $v$. Wag$n e r,{ }^{56}$ the court stated:

"The objection that an allowance is subject to alteration by the court ordering it, and so it cannot be regarded as a final and conclusive judgment, has little, if any, weight as to an

${ }^{8 I}$ Supra note 33 .

${ }^{82}$ See Levine v. Levine, 95 Ore. 94, I01-r02, 187 Pac. 609 (1919).

${ }^{23}$ Israel v. Israel, $x 48$ Fed. 576 (C. C. A. 3rd, I906): In a New York divorce action the husband had been ordered to pay the wife $\$ 30$ a week for the support of herself and children until the further order of the court, and $\$ 223.85$ as costs. In an action of assumpsit brought by the wife in the District Court of Pennsylvania, judgment was given which included $\$ 2,130$ representing alimony and maintenance for 71 weeks, of which sum $\$ 120$, or alimony for four weeks, was payable on the rendition of the Ncw York decree. The balance had accrued thereafter. "It appears that under the statutes of New York the judgment or decree, so far as it directed the payment of alimony and maintenance not then accrued or payable could at any time thereafter be annulled, varied or modified by the court rendering it. It, therefore, was not a conclusive and final judgment or decree with respect to the sum of $\$ 2,010$, representing alimony and maintenance for sixty-seven weeks accruing after its rendition. It did not constitute a fixed, unconditional and absolute liability for its payment." Per Bradford, J., pp. 577-578. It was held that if the plaintiff remitted the excess over $\$ 120$ and costs, the judgment would be affirmed.

See also Freund v. Freund, 7I N. J. Eq. 524, 63 Atl. 756 (1906): "This decision [Lynde v. Lynde] controls the earlier decision of Barber v. Barber, ... and overrules it, if it be inconsistent." Aff'd without opinion, 72 N. J. Eq. 943, 73 Atl. III7 (1906).

Valiquet v. Valiquet, I77 Fed. 994,996 (C. C. D. N. J. 1909): "The bill shows that all of the alimony which had accrued, according to the decree, has been paid. As to the alimony thereafter and from time to time made payable, the decree was not a final judgment for a fixed sum." Per Cross, J.

See also Bleuer v. Bleuer, 27 Okla. 25, 110 Pac. 736 (rgro); compare Campbell v. Campbell, 28 Okla. 838, II5 Pac. IIII (IgIr).

Ex Page v. Page, 189 Mass. 85, 91, 75 N. E. 92 (Ig05): "In order to bring herself within the provision the plaintiff must show that the decree (of Maine court awarding $\$ 6$ week) was final. The decree had reference simply to future payments, and generally a decree in the form of this one is subject to modification by the court which passed it."

${ }^{E 5} 32$ Utah 428, 436, 9I Pac. 269, 272 (1907). The plaintiff had not alleged that the Colorado decree was final nor had she set forth Colorado statutes or decisions to that effect. Judgment for the plaintiff was reversed.

${ }^{50} 26$ R. I. 27, 29, 57 Atl. 1058 (1904), per Stiness, C. J. 
amount already due at the time of suit. An accrued amount would not be changed by the court if the debtor was able to pay it, and a suit on a decree is but a step to enforce such payment."

The decision to a large extent was placed upon the grounds of public policy. ${ }^{57}$ The needs of the wife are the same whether she sues in $F_{-I}$ or $F_{-2}$. Other courts took the same position. 58

Thus, as the result of the Lynde case the effectiveness of the wife's remedy in $F_{-2}$ was curtailed materially. As a practical matter, in but few cases did the court decide that alimony was due and owing at the time of the $F-I$ decree. And again, most decrees calling for future payments were, as they should be, subject to modification at the hands of the $F_{-I}$ tribunal.

A few years later the Supreme Court of the United States again had occasion to deal with the matter, this time in the case of Sistare v. Sistare. ${ }^{59}$ In I899 a New York court had granted the plaintiff wife a separation from bed and board and had ordered the defendant husband to pay her weekly $\$ 22.5^{\circ}$ for the support of herself and a minor child. It was further ordered that the plaintiff have leave to apply, from time to time, for such orders at the foot of the judgment as might be necessary for its enforcement and for the protection and enforcement of her rights. Furthermore, a New York statute provided that the court might, upon the application of either party, after due notice to the other, by order, annul, vary or modify such directions. ${ }^{60}$ In July, I904, none of the installments of alimony having been paid, and the New York decree not having been altered, modified or annulled, the wife sued in Connecticut to recover the amount then in arrears. The trial court gave her judgment for $\$ 5,805$, the arrears of alimony due at the time of the commencement of the action. On appeal this decision was reversed by the Supreme Court of Errors. ${ }^{61}$ The court held that by the laws of New York the decree was not final, even as to accrued installments. ${ }^{62}$ The decree calling for future payments, even though those sued for were accrued and due, did not, therefore, constitute a debt of record. It was not a final judgment which by virtue of the full faith and credit clause it was the duty of

\footnotetext{
${ }^{87}$ Id. at 28, 57 Atl. ro58 (rgo4): "The tendency of courts, and the better reason, is in favor of enforcing such decrees where the only question involved is the payment of money. An obvious advantage in this course is that it tends to unify the remedial agencies of the country by making them enforceable in all its parts. It would be a reproach to our system of legal administration if one could escape from the operation of a judicial decree by going into another state. This is one country, and so far as possible it should have one law. Whatever tends to make the operation of law and legal remedies equally effective in all parts of the land is carrying out the true idea of a common country. A party against whom a judgment stands should not be shielded by the fact that he is not in the state where it was rendered. In a state where a decree is given for allowance at stated periods it would be enforced and so it should be enforced elsewhere it can be."

${ }^{08}$ Rogers v. Rogers, 46 Ind. App. 506, 89 N. E. 901 (1909), rehearing denied, 46 Ind. App. 506, 92 N. E. 664 (1909); Moore v. Moore, 40 Misc. 162, 8I N. Y. Supp. 729 (1903).

208 U.S. I (1909).

${ }^{\circ}$ N. Y. Crv. Prac. Act, \$IIjo, formerly Code Crv. Proc., \$r77I.

ox Sistare v. Sistare, 8o Conn. I, 66 Atl. 772 (1907).

02 "The right of modification or annulment which is thus reserved to the courts is one which extends to overdue and unsatisfied payments as well as to those which may accrue in the future." Id. at 4, 66 Atl. at 773 (rgo7), per Prentice, J.
} 
the Connecticut court to enforce. It was felt that Lynde v. Lynde did not overrule Barber v. Barber, but since the New York decree was not final, the Lynde case controlled. ${ }^{63}$

In the Supreme Court of the United States, on writ of error brought by the wife, the holding of the Supreme Court of Errors of Connecticut was reversed and that of the trial court affirmed. ${ }^{64}$ Mr. Justice White formulated the issue in these terms:

"Where a court of one state has decreed the future payment of alimony, and when an installment or installments of the alimony so decreed have become due and payable and are unpaid, is such a judgment as to accrued and past-due alimony ordinarily embraced within the scope of the full faith and credit clause of the Constitution of the United States so as to impose the constitutional duty upon the court of another state to give effect to such judgment?"

In answering this question, Mr. Justice White held that the two cases were not in conflict, as contended by the opposing counsel, and if they were "Lynde v. Lynde must be restricted or qualified so as to cause it not to overrule the decision in the Barber case." 68 This conclusion was reached on the following grounds. In the first place, while in the Lynde case no reference was made to Barber v. Barber, it could not be said that the earlier case was overlooked, because it was referred to by the court below and was cited and commented on in the briefs of counsel in the Lynde case. In the second place, in view of the careful opinion in the Barber case and of the long interval between the two cases, and the fact that the state courts had uniformly accepted the rule laid down in Barber v. Barber, it could not be conceived that the short opinion in Lynde v. Lynde was intended to change the settled rule of constitutional construction which had so long prevailed. ${ }^{87}$ Interpreting the two cases as in harmony with each other:

"It results: First, that generally speaking, where a decree is rendered for alimony and is made payable in future installments, the right to such installments becomes absolute and vested upon becoming overdue, and is therefore protected by the full faith and credit clause, provided no modification of the decree has been made prior to the maturity of the installments, since, as declared in the Barber case, 'alimony decreed to a wife in a divorce of separation from bed and board is as much a debt of record, until the decree has been recalled, as any other judgment for money is.' Second, that this general rule, however, does not obtain where, by the law of the state in which a judgment for future alimony is rendered, the right to demand and receive such future alimony is discretionary with the court which rendered the decree, to such an extent that no absolute or vested right attaches to receive the installments ordered by the decree to be paid, even although no application to annul or modify the decree in respect to alimony has been made prior to the installments becoming due." 68

es "When rightly interpreted there is no lack of harmony between them." Id. at 7, $66 \mathrm{Atl} .772$ (1907). es Supra, note 6r.

${ }^{\circ 0} 218$ U. S. I, II (Ig09).

${ }^{87}$ Mr. Justice White said that the ruling in the Lynde case was expressly based upon the latitude of discretion which the New Jersey courts were assumed to possess over a decree for the payment of future alimony. Id. at $\mathrm{x5}$-I 6 .

${ }^{\mathrm{es}} 7 d$. at $16-\mathrm{I} 7$. 
It was then found that the New York statutes did not expressly give the power to revoke or modify the accrued installments. They were not, therefore, so completely within the discretion of the court as to bring them within the exceptional rule embodied in the second proposition set forth above.

"And every reasonable implication must be resorted to against the existence of such power, in the absence of clear language manifesting an intention to confer it." 69

The Sistare case thus promulgated a test to be employed to determine whether full faith and credit is to be given an $F_{-I}$ alimony decree directing payment in future installments in case the wife seeks in $F_{-2}$ to collect the accrued sums. If the $F_{-I}$ court can alter, modify or annul even as to the accrued installments, the $F-2$ tribunal need not allow recovery thereon. But if the decree cannot be so altered, modified or annulled, it must be recognized. The whole problem thus becomes one of resolving the power of the $F-I$ court. The case further formulated a rule of construction. If a statute or decree does not in clear and express words grant or reserve the power to alter or annul, every reasonable implication is to be resorted to against such power. Every effort is to be made to apply the rule of the Sistare case. It seems to be the desire of the court to enforce such installment payments wherever possible, but at the same time to adhere to the patterns laid down for the enforcement of foreign money judgments generally. The tests laid down in the Sistare case have apparently been adequate because in the thirty years since that decision no other case, on this exact point, has been considered by the Supreme Court.

The state courts have consistently followed the rule of the Sistare case. Where $W$ has obtained in $F-I$ a decree for alimony payable in future installments, the decree being unalterable and revocable as to accrued sums, she has uniformly been held entitled to recover these payments in $F_{-2 .}{ }^{70}$ Very properly every effort has been made to make the wife's claim enforceable. This is as it should be. But the state courts have refused to give full faith and credit to the $F-I$ decree where such decree is so within the discretion of the $F-I$ court as to past due installments that the qualification mentioned by Mr. Justice White applies. Thus, where $W$ has secured a decree for

${ }^{\circ 0}$ Id. at 22, per White, J.

${ }^{70}$ Cotter v. Cotter, 225 Fed. 47r, 475 (C. C. A. 9th, r915): "In Washington, while the court may discontinue alimony permanently when granted in monthly installments until further order of the court, it may not modify a decree as to installments of alimony past due and unpaid." Per Wolverton, J.; Straus v. Straus, 4 Cal. App. (2d) 46r, 4 I P. (2d) 218 (I935); Phillips v. Kepler, 47 App. D. C. 384 (I918); Carmona v. Naron, 37 Idaho 482, 217 Pac. 597 (1923); Paulin v. Paulin, 195 Ill. App. 350 (I915); Rosenberg v. Rosenberg, 152 Md. 49, I35 Atl. 840 (I927); Taylor v. Stowe, 218 Mass. 248, 105 N. E. 890 (rgr4); Gutowski v. Gutowski, 266 Mich. x, 253 N. W. I92 (r934); McCullough v. McCullough, 203 Mich. 288, ro5 N. W. 890 (I9I8); Tehsman v. Tehsman, 93 N. J. Eq. 76, II4 Atl. 320 (I92I); Bolton v. Bolton, 86 N. J. L. 622, 92 Atl. 389 (rgr4); Babcock v. Babcock, I47 Misc. 900, 265 N. Y. Supp. 470 (1933), aff'd, 239 App. Div. 884, 265 N. Y. Supp. 474 (1933), appeal dism'd, 263 N. Y. 665, I89 N. E. 747 (1934); Beech v. Beech, 2 II App. Div. 720, 208 N. Y. Supp. 98 (1925); Van Horn v. Van Horn, Ig6 App. Div. 472, I88 N. Y. Supp. 98 (I921); Tiedemann v. Tiedemann, 172 App. Div. 8I9, I58 N. Y. Supp. 851 (rgr6); Williamson v. Williamson, I69 App. Div. 597, I55 N. Y. Supp. 423 (1915); Patton v. Patton, 67 Mísc. 404, 123 N. Y. Supp. 329 (1910); Armstrong v. Armstrong, xx7 Ohio St. 558, 160 N. E. 34 (1927); Campbell v. Campbell, 28 Okla. 838, I15 Pac. IIrI (I9II); De Vall v. De Vall, 57 Ore. 128, 109 Pac. 755 (1910); Stewart v. Stewart, I93 Atl. 860 (N. J. I937); Caples v. Buell, 234 S. W. 429 (Tex. Civ. App. 192I); Caples v. Caples, 47 F. (2d) 225 (C. C. A. 5th, 193I). 
future alimony in $F-I$, which is there subject to the discretion and power of the $F-I$ court, even as to accrued installments, she has been denied relief in $F-2$, under the qualification of the rule in Sistare v. Sistare. ${ }^{71}$ The judgment even in $F-I$ was in no sense final.

The law of $F-I$, statutory as well as judicial, thus becomes the determining factor in deciding whether the $F_{-I}$ decree calling for installment payments is to be enforced in $F$-2. The proof of the $F-I$ law is, therefore, of paramount importance. On this point no uniform policy has been adopted. A number of courts require the plaintiff to allege and prove that the $F_{-I}$ decree, as to accrued installments, is not subject to modification. In Lape v. Miller, ${ }^{72}$ the court said:

"Courts of one state do not take judicial knowledge of the laws of another one, whether they be statutory or of judicial determination; and the existence of such laws, as well as their import, force and effect, must be proven, if denied, the same as any other fact in issue." 73

Other courts throw the burden of proving the $F-I$ law upon the defendant. In Curran v. Curran, ${ }^{74}$ the court stated:

"Here there is no proof by the defendant, ... to show that the right to recover the arrears of alimony is not a vested one. Nor has it been shown that the decree has been modified prior to the coming due of the installments."

The courts which adopt this view indulge in a presumption that the $F-I$ decree is final in regard to accrued installments. ${ }^{75}$ This view is preferable both from the legal and the social standpoint. The defendant is trying to escape compliance with the $F-I$ judgment; the burden, therefore, should be placed on him. Every effort should be

${ }^{71}$ McAlister v. McAlister, 214 Ala. 345, I07 So. 843 (x926) [in regard to a Louisiana decrec]; Lape v. Miller, $203 \mathrm{Ky} \cdot 742,263 \mathrm{~S}$. W. 22 (I926) [the defendant had answered that the Ohio decree was not final even as to accrued installments, and it was held that the plaintiff's demurrer thereto should have been overruled, the court refusing to take notice of Ohio law]; Webster v. Webster, 177 La. 306, 148 So. 24I (1933) [where it was held that under Michigan law even accrued installments remained subject to court modification; Mrсн. Comp. Laws (1929) §12747; Skinner v. Skinner, 205 Mich. 243, I7x N. W. 383 (Igrg)]; Gallant v. Gallant, 154 Miss. 832, 123 So. 883 (r929) [in regard to Louisiana law; Ln. Civ. CODE (Dart, r932) art. 160]; Bentley v. Calabrese, 155 Misc. 843,280 N. Y. Supp. 454 (1935) [in regard to Massachusetts law, Williamson v. Williamson, 246 Mass. 270, 140 N. E. 799 (1923); McElroy v. McElroy, 208 Mass. 458, 94 N. E. 696 (IgrI); Hill v. Hill, I96 Mass. 509, 82 N. E. 690 (1907), Miss. GeN. LAws (x932), c. 208, \$37]; Smith v. Smith, 249 App. Div. 660, 291 N. Y. Supp. 635 (1936) [in regard to New Jersey law]; Levine v. Levine, 95 Ore. 94, 187 Pac. 609 (1920) [in regard to Minnesota law]; Hanson v. Hanson, I8 F. Supp. 527 (M. D. Pa. 1937) [where the court followed the interpretation of New Jersey law laid down in Lynde v. Lynde]; Hewett v. Hewett, 44 R. I. 308, I16 Atl. 883 (1922) [in regard to Massachusetts law]; Gaffey v. Criteser, I95 S. W. I I66 (Tex. Civ. App. I9I7), af'd, Criteser v. Gaffey, 222 S. W. 193 (1920) [in regard to Oregon law]; Ogg v. Ogg, x65 S. W. 912 (Tex. Civ. App. 1914) [in regard to New York law].

${ }_{72} 203 \mathrm{Ky} \cdot 742,746,263$ S. W. 22 (1924), per Thomas, J.

${ }^{73}$ Accord: Page v. Page, stipra note 54; Ogg v. Ogg, supra note $7 \mathrm{I}$.

74136 Misc. 598, 600, 240 N. Y. Supp. 64 (1930), per Noonan, J.

${ }^{75}$ Alexander v. Alexander, 164 S. C. 466,472 , I62 S. E. 437 (1932): "The finality of the Maryland decree as to the right of the plaintiff to payments fully matured under its provisions must be presumed when there is no proof of any Maryland law to the contrary." Per Blease, C. J. See also Phillips v. Kepler, 47 App. D. C. $3^{84}, 387$ (r9r8). 
made in $F_{-2}$ to enforce the decree. A few courts of their own accord examine the law of $F-x$. In Hewett $v$. Hewett, ${ }^{76}$ the court said:

"The case is before us on demurrer and unless we take judicial notice of the laws of Massachusetts we have no information as to whether the plaintiff by virtue of the decree in question has a vested right to demand and receive the installments which have become due."

And above all it is to be noted that the courts follow the rule of construction set forth by Mr. Justice White in Sistare v. Sistare. This policy has been well expressed in Phillips v. Kepler:"7t

"If we may reason from the rule which obtains in statutory construction, a retroactive effect should not be given to the exercise of any power to recast a decree, unless the language defining the power leaves no choice."78

On the whole the state courts have adhered rather closely to the federal doctrine enunciated in Sistare $v$. Sistare. ${ }^{79}$ They have not given effect to the $F-I$ decree unless required to do so by the full faith and credit clause.

At this point reference must be made to the Minnesota case of Holten $v$. Holten. ${ }^{80}$ The plaintiff had obtained in Oregon a divorce with alimony of $\$ 150$ a month during her lifetime. The husband having moved to Minnesota, and the wife having applied to the divorce court for a judgment covering the unpaid installments, a decree was entered in her favor for $\$ 6,076.75$. She then sued the defendant in Minnesota to recover this sum. The trial tribunal, finding that the Oregon court did not have power to modify accrued installments, ${ }^{81}$ gave judgment for $\$ 6,076.75$ with interest. While the Supreme Court of Minnesota did not agree as to this point with the trial court the decision was affirmed. ${ }^{82}$ The court said:

"Following Sistare v. Sistare, we hold that so long as the judgment is absolute in its terms and remains unmodified, or at least until an application for modification has been made, it is final as to instalments of alimony which have accrued. Sound public policy forbids the adoption of a rule which would permit a husband to escape his obligation to support his wife or infant children by crossing a state line." 83

For reasons of policy the court excluded the qualification of the general rule enunciated in Sistare $v$. Sistare, ${ }^{84}$ and held that even if a judgment for alimony is subject to modification as to accrued installments, it is still entitled to full faith and credit in $F-2$, so long as no application for modification appears to have been made. It is thus in conflict with Lynde v. Lynde, ${ }^{85}$ going much further than is required by the

${ }^{70} 44$ R. I. 308, 3I0-3II, II6 Atl. 883 (I922), per Rathbun, J. Contra: Lape v. Miller, supra note 7r.

7747 App. D. C. 384,387 (1918), per Smyth, C. J.

${ }^{78}$ See also Campbell v. Campbell, supra note 7o; Levine v. Levine, supra note $7 \mathrm{I}$.

${ }^{70}$ See the cases cited in notes 70 and $7 r$.

${ }^{80}$ I53 Minn. 346 , I90 N. W. 542 (1922). $\quad{ }^{81} I d$. at 348, rgo N. W. 542.

89 "We also hold that irrespective of the so-called judgment of December 31, 1919 [the Oregon judgment for accrued alimony], the plaintiff was entitled to recover the amount of the installments which had accrued." Id. at 352 , Igo N. W. 542, 544, per Lees, C.

${ }^{83} \mathrm{Id}$. at $35 \mathrm{I}, \mathrm{Ig0} \mathrm{N}$. W. 542,544 .

${ }^{84}$ See stipra note 59.

${ }^{85}$ Supra note 45. 
full faith and credit clause. The rule is apparently broadened to include all decrees for alimony. Though improperly based on the full faith and credit clause, where no application has been made to modify the $F-I$ decree, the decision might be justified on the ground of comity, ${ }^{86}$ on the theory that the Supreme Court merely prescribed the minimum recognition which must be accorded the $F-I$ decree. It is submitted that Holten v. Holten exhibits an enlightened policy.

The California courts and those of a few other states have gone still farther. They have established the $F-I$ decree as a judgment of their own courts. ${ }^{87}$ The decree can thus be enforced as a domestic judgment. New York by statute has in a limited type of case done something much the same. ${ }^{88}$

Hitherto our discussion has been devoted to the problem of permanent alimonynothing has been said concerning the recovery in $F-2$ of payments accruing under an $F-I$ decree for alimony pendente lite. ${ }^{88}$ The object is to provide for the wife during the pendency of some matrimonial suit. Such an award is always subject to modification or revocation by the court which granted it.

"An award of temporary alimony creates a mere personal right limited in its enforcement to the proceeding pending which it was granted. In re Hudes' Estate, 128 Misc. 362, 219 N. Y. S. 435. All proceedings to compel the payment of temporary alimony are limited to the action in which the order for alimony was granted. . . Thus it would appear that temporary alimony awarded in the State of New York may not be reduced to final judgment under the Practice Act of that state."90

This being the situation, it is not at all surprising to find that the $F-2$ courts follow the qualification laid down in Sistare v. Sistare, and refuse to enforce an F-I decree for alimony pendente lite. This is the position very generally taken. ${ }^{01}$ Not being a final judgment for an absolute debt, the husband's duty being subject to modification, "no action can be maintained on a mere interlocutory order for alimony pendente lite."

${ }^{80}{ }_{41}$ A. L. R. I4I9, 142X (1926).

${ }^{87}$ Palen v. Palen, 12 Cal. App. (2d) 357, 55 P. (2d) 228 (1936); Straus v. Straus, 4 Cal. App. (2d) 46I, 4x P. (2d) 218 (1935); Creager v. District Court, x26 Cal. App. 280, 14 P. (2d) 552 (r932); Cummings v. Cummings, 97 Cal. App. 144 , 275 Pac. 245 (r929).

${ }^{88}$ N. Y. Civ. Prac. Act, $\$ \$ 117 x$, II72.

${ }^{80}$ See 2 Vernier, AMertcan FaMily Laws 309-321, 460-462.

${ }^{90}$ Kelly v. Kelly, I2I N. J. Eq. 36r, 362-363, x89 Atl. 665 (1937), per Rafferty, J. Sce Doncourt v. Doncourt, 245 App. Div. 9r, 28I N. Y. Supp. 535 (1935); N. Y. Civ. PRAC. ACr, \$r169.

${ }^{91}$ Kelly v. Kelly, supra note 90. The plaintiff wife sued in New Jersey to recover. the arrears of alimony pendente lite awarded in a New York divorce suit. A decree in favor of the plaintiff was reversed. Since under New York law accrued temporary alimony is subject to extinguishment by the termination of the action, it may also be modified. "If the prerequisite judgment may not be entered in the New York courts which granted the award of temporary alimony, that award may not be enforced in another forum. Further, if temporary alimony may not form the basis for an independent action in New York and if proceedings for the collection of any arrears of temporary alimony must be brought in the action in which the order was granted and is not otherwise enforceable, it would seem illogical to permit temporary alimony to form the basis of an independent action in a foreign jurisdiction." Per Rafferty, J., at 365.

Hamilton v. Hamilton, 113 Conn. 306, 155 Atl. 217 (1931); Geisler v. Geisler, $124 \mathrm{Ky} .292$, 98 S. W. I023 (1907); Mills v. Mills, 95 Misc. 231, 158 N. Y. Supp. 753 (1916); Van Horn v. Van Horn, 48 Wash. 388, 93 Pac. 670 (1908); Henry v. Henry, 74 W. Va. 563, 82 S. E. 522 (1914).

${ }^{02} 2$ BEALE, Conflict of LAws 1393. Compare Paul v. Paul, I2I Kan. 88, 90, 245 Pac. 1022 (1926),

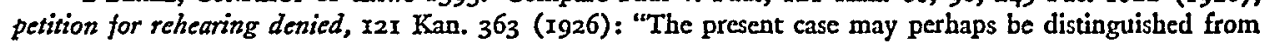


Again, it would seem that the courts are being overly technical; that they are unduly influenced by the law concerning the extraterritorial enforcement of money judgments in general; that they have failed to consider the social problems involved in the award of temporary alimony. Here, even more than in the case of permanent alimony, is the award based upon the necessities of the wife. If the husband is able to escape his obligations by going to $F-2$, something is the matter with the law in this field.

So far we have discussed alimony that is due and payable. We must now turn to the problem of future installments. What can the wife do in $F_{-2}$ in regard to such? Not having accrued, not being due and owing, they are not a debt within the technical meaning of the term. Generally by express reservation in the decree or by statute the $F-I$ court is empowered to revoke or modify such future payments. ${ }^{93}$ Certainly, under the qualification enunciated in the Sistare case, ${ }^{94}$ it would seem clear that the Supreme Court would not require that full faith and credit be accorded thereto.

The enforcement of future payments necessitates making the $F_{-I}$ judgment a decree of the $F-2$ tribunal. This would enable the wife to invoke the sanctions available to one obtaining a local alimony decree.

From a social standpoint, much can be said in favor of such a view. In the first place, instead of forcing the wife to sue again and again for accrued payments as they become due, she would have a more effective remedy. Again, a delinquent husband would not be favored, as he now is in $F_{-2}$, but would be subject to the full sanctions of a local decree. Certainly, no one would quarrel with this. Furthermore, it is clearly in the public interest that the husband's obligation to support his wife and children be enforced up to the hilt. Lastly, the fact that the decree is subject to modification by the $F_{-I}$ tribunal would of itself be no reason why it should not be made a decree of $F-2$, especially where no such modification has occurred. That forum can by appropriate action conform its decree thereto.

Those courts which adhere to the strict analysis of Sistare $v$. Sistare, bothered as they are by the "lump concept" of viewing a decree for alimony as a mere money judgment, uniformly deny such enforcement to the plaintiff. On the basis of the enforcement of money judgment generally, this is logical, but it is submitted that there is more at stake where problems of support are involved. These courts say that the plaintiff has ample protection by bringing her action for accrued installments. ${ }^{95}$

these [supra] by the fact of the order for temporary alimony having explicitly been made enforceable by execution, giving it to that extent the character of a final judgment." Per Mason, J. See also Wallace v. Wallace, rix Cal. App. 500, 295 Pac. I06I (x931).

${ }^{93}$ See supra note 30 .

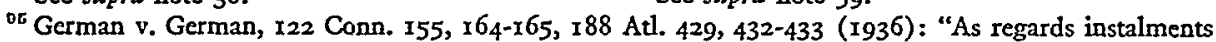
due in the future, there would be no question of the power of the courts of New York to modify the decree. ... The decree before us is not, therefore, enforceable in our courts as regards payments falling due in the future." Per Maltbie, C. J. See also Kossower v. Kossower, r42 Atl. 30 (N. J. I928).

Alexander v. Alexander, I64 S. C. $466,476-477,162$ S. E. 437 (1932): "In Maryland courts of equity have power to modify provisions as to alimony in decrees of divorce $a$ mensa or $a$ vinculo and retain 
But a few courts, led by California, have allowed the plaintiff to establish the $F-r$ decree as a decree of the $F-2$ tribunal, and give enforcement thereto the same as to a local decree. ${ }^{96}$ In Cummings v. Cummings, ${ }^{97}$ the judgment was for a sum equal to the amount due under the New York judgment, including all installments down to the entry of the judgment, and for $\$ 65$ per month thereafter, but only so long as the decree of the New York court remained unmodified, leave being given to apply for a modification if the New York court modified its decree, giving the plaintiff the equitable relief to which she would be entitled under a California decree. ${ }^{08}$ In Palen v. Palen, ${ }^{99}$ the court said:

"It is settled that a judgment for alimony obtained in another state may be established in this state for the purpose of enforcing it as a continuing judgment in this state for the payment of alimony."

The courts of a few other states have been willing to do the same thing. ${ }^{100}$ This trend, while still imperceptible, is, it is submitted, clearly a step in the right direction.

If the decree is final and not subject to modification even as to the future installments, what about the situation?101 Would the position taken primarily by the California courts be more sound? Possibly so, but the argument can still be made that the installments not having accrued, they are not due and do not constitute a debt. Therefore, the decree will not be enforced until the payments have become due. The question really is whether the $F-I$ decree is to be enforced at law or in

continuing jurisdiction over such decrees as to future payments of alimony. For these reasons the decree is not a final one in respect to the future payments of alimony." Per Blease, C. J.

${ }^{\circ 0}$ See cases cited in note 87 , supra.

${ }^{07} 97$ Cal. App. I44, 275 Pac. 245 (1929), discussed in (1932) 29 Col. L. REv. 832.

us Creager v. Superior Court, I26 Cal. App. 280, 14 P. (2d) 552 (1932), discussed in (r933) 81 U. of PA. L. Rev. 342: Petitioner's wife was granted a divorce by a Nevada court, and the petitioner was ordered to pay $\$ 30$ a month alimony. By a bill in equity in California she secured an order directing payment of the amount in arrears and establishing the Nevada decree. On the petitioner's failure to observe this decree, the court ordered him to show cause why he should not be adjudged guilty of contempt for failure to comply with its decree. The petitioner then brought a writ of prohibition, claiming that there was no equitable jurisdiction in the California court, since the Nevada decree was enforceable there only as a money judgment. It was held that the equitable enforcement was proper. "We think it entirely clear that the judgment of the respondent court gave full faith and credit to the Nevada decree in its entirety. By its terms the Nevada judgment was 'established hercin as a foreign judgment.' If such recognition excecds the requirements of the federal Constitution, but is authorized by the laws of this state, petitioner may not complain. ... For the purpose of enforcement in this state, we believe that the respondent court properly treated its own judgment, based upon and establishing the Nevada judgment, in the same manner as an award of alimony by the respondent court." Per Spence, J., pp. 282-283.

${ }^{89}$ I2 Cal. App. (2d) $357,358,55$ P. (2d) 288 (1936), per Gould, J. Here a Missouri judgment was established as a judgment of the California court. In Straus v. Straus, supra note 87 , the same was done with a New York decree.

${ }^{100}$ Fanchier v. Gammill, 148 Miss. 723, II4 So. 813 (I927), discussed in (I928) 4 I Harv. L. Rev. 798; Cousineau v. Cousineau, 155 Ore. 184,63 P. (2d) 897 (r936); Shibley v. Shibley, r8r Wash. $x 66$, 42 P. (2d) 446, 97 A. L. R. II9I (I935).

In Fanchier v. Gammill, the court said: "A decree for alimony granted by a foreign court may be established and enforced by and through courts of equity in one state, and that our equity courts may assume jurisdiction of the alimony decree and establish and enforce it." Per Holden, J., at 737.

101 This was the situation in Fanchier v. Gammill, supra note I00, and in Creager v. Superior Court, supra note 98 . By Nevada practice an alimony decree is not open to modification. Sweeney v. Swecney, 42 Nev. 431, r79 Pac. 638 (rgrg). 
equity. At law relief can be given only for what is due, while equity may direct payment in the future.

Let us now summarize the law as it has developed since the case of Barber $v$. Barber. An alimony decree of a court of competent jurisdiction in $F-I$, is, under certain circumstances, a debt of record, entitled to full faith and credit in F-2. If it calls for a lump sum payment, it will, on the analogy of an ordinary money judgment, be enforced. Where the decree calls for periodic payments, it is enforceable in $F-2$ as to the sums due only if the $F-r$ court has not the power to alter or revoke the accrued installments. But if the $F_{-I}$ court has such power, then, since no right to alimony vests in the wife, she cannot recover even the sums which have accrued, save in a few states. In such a case, however, if she gets the $F_{-I}$ tribunal to give a judgment for the sums due, such judgment, like any other money decree, will serve as the basis for an action in $F-2$. Where the language of the $F-I$ statute or decree reserving the power to alter or annul is not perfectly clear, every reasonable implication is resorted against the existence of such power. Furthermore, most jurisdictions as we have seen, refuse to give any effect to payments which have not fallen due. A few states, it is true, have established the $F_{-I}$ decree as a judgment of their own courts in order to enforce future payments. And lastly, no action can be maintained on an interlocutory order of $F_{-I}$ for alimony pendente lite.

We must now consider how and in what ways the $F-2$ court will enforce the $F-I$ decree for alimony. Hitherto our discussion has been in regard to the type of alimony which $F-2$ must recognize. In German v. German, ${ }^{102}$ the court stated:

"The constitutional provision, however, only requires that the courts of a state other than that in which the decree is rendered shall give effect to it by the ordinary remedies appropriate to an action upon a judgment; that court is not required to apply any special remedies provided by the laws of the State in which the decree was rendered, nor any special remedies provided by its own laws to enforce similar decrees made by its own courts."103

Thus, under proper circumstances, $F_{-2}$ must give full faith and credit to the $F-I$ alimony decree; it is a final and conclusive adjudication of the rights of the spouses. But it has been stated again and again that $F_{-2}$ need not give to the wife the special remedies to which she would have been entitled in $F-r_{0}{ }^{104}$ Certainly it would not be expected that $F-2$ should give the wife remedies which it is not empowered to use in the enforcement of its own decrees. And similarly the position has been taken quite

${ }^{103} 122$ Conn. 155, 158, 188 Atl. 429 (1936), per Maltbie, C. J.

${ }^{103}$ See M'Elmoyle v. Cohen, supra note 23. 2 Beale, Conflict of Laws 1377: "The method of enforcement of a foreign judgment is governed by the law of the forum."

${ }^{10}$ Lynde v. Lynde, supra note 45; Sistare v. Sistare, supra note 59; White v. White, 223 Mass. 39, 123 N. E. 389 (19I9); Bullock v. Bullock, 5I N. J. Eq. 444, 27 Atl. 435 (1893); Tiedemann v. Tiedemann, 172 App. Div. 819, I58 N. Y. Supp. 851 (1916). In the latter case, the court stated: "But this duty does not require the enforcement of the judgment of the sister state, and, therefore, does not apply to the provisions of a judgment in a suit in equity which are incidental to the main relief, and are in the nature of an execution of the judgment itself. . . . But if the courts of this State should require the defendant to account for any community property there may be here, that would be enforcing the Nevada decree and the incidental provision thereof based upon the statute law of that State which has no extraterritorial effect. . . " Per Laughlin, J., at 824-825. 
generally that the special remedies available in regard to a local alimony decree are not open to the wife. ${ }^{105}$

The enforcement of a foreign judgment, at common law, was by an action of debt. This is still the ordinary remedy by which to enforce a foreign money judgment. On the theory that a decree for alimony is a mere money judgment, the $F-2$ courts very generally restrict the wife to an action of debt. ${ }^{100}$ According to these courts, the $F-I$ alimony decree is, when before them, merely a debt of record just like any other debt, having lost any special characteristics it may have had as a decree for alimony. ${ }^{107}$ Crossing the state frontier, therefore, produces far-reaching effects-the alimony decree becomes a mere money judgment for which the appropriate remedy is an action at law-no resort to equity being permitted because the legal remedy is plain, adequate and complete. ${ }^{108}$

\section{Mr. Justice Wayne said in the famous case of Barber v. Barber:109}

"And such a judgment or decree, rendered in any state of the United States, the court having jurisdiction, will be carried into judgment in any other state, to have there the same binding force that it has in the state in which it was originally given. For such a purpose, both the equity courts of the United States and the same courts of the states have jurisdiction."

Had this language been followed, the law concerning the enforcement of foreign alimony decrees would have developed along quite different lines. But it was in conflict with the statements $\mathrm{Mr}$. Justice Wayne had made many years before in M'Elmoyle v. Cohen. ${ }^{110}$ And it was not until sixty-nine years after these words were uttered that a court for the first time proceeded in accordance therewith. In Fanchier (Ig00).

${ }^{105}$ Lynde v. Lynde, 4 I App. Div. 280, 58 N. Y. Supp. 567 (I899), aff'd, 163 N. Y. 405,56 N. E. 979

${ }_{108}$ Grant v. Grant, 75 F. (2d) 655 (App. D. C. r935), where the wife's bill in equity to have the court direct the defendant "to specifically perform" a Maryland alimony decree was dismissed; Davis v. Davis, 29 App. D. C. 258, 263 (1907), where the wife's prayer for the exceution of a Kansas decree was denied for want of jurisdiction in equity, because she had an adequate remedy at law, Shepard, C. J., stating: "For all purposes of its enforcement in this jurisdiction, therefore, the award of alimony (Kansas decree) is to be regarded as a debt, merely, and enforceable only as such by execution at law"; Worsley v. Worsley, 76 F. (2d) 815 (1935), where the wife's bill to enforce a Virginia alimony decree was dismissed on authority of Grant v. Grant and Davis v. Davis; Weidman v. Weidman, 274 Mass. II 8, 174 N. E. 206 (193I), discussed in (193I) 29 Mrch. L. Rev. ro7x, compare White v. White, 223 Mass. 39, x23 N. E. 389 (1919); Page v. Page, I89 Mass. 85, 75 N. E. 92 (1905); Mayer v. Mayer, 154 Mich. 386, I17 N. W. 890 (r908), where contempt proceedings were held not available to enforce an Ollahoma decree; Kossower v. Kossower, 142 Atl. 30 (N. J. 1928); Bennett v. Bennett, 63 N. J. Eq. 306, 49 Atl. 50 (190x), where the court refused to enforce a North Dakota decree, saying: "This provision (the full faith and credit clause) does not make the foreign decree or judgment a record to be enforced without further procecdings in the state to which it is taken, nor does it refer to the remedy or means of enforcing it, but only provides that the facts found in the foreign court upon which the judgment or decree was entered cannot be inquired into by the courts of the sister states." Per Voorhees, J., pp. 307-308; Wood v. Wood, 7 Misc. 579,28 N. Y. Supp. 154 (1894).

Compare Wagner v. Wagner, supra note 27.

Mrch. Comp. Laws (1929) $\$ \$ 12770-12772$, provide that the foreign alimony decree is enforceable by an action at law.

${ }_{107}$ See cases cited in note ro6; also White v. White, 223 Mass. 39, 139 N. E. 389 (1919).

${ }^{208}$ Davis v. Davis, supra note ro6; Bennett v. Bennett, supra note xo6.

${ }^{102} 21$ How. 582, 591 (U. S. I858). $\quad{ }_{110}$ Supra note 23. 
v. Gammill, , $^{111}$ a wife who had secured in Nevada a divorce with alimony payable in installments, brought a bill in equity in Mississippi to enforce the decree and to recover the arrears. On appeal the judgment sustaining the defendant's demurrer was reversed. On policy grounds the wife was not restricted to legal execution; the $F_{-2}$ equity court may enforce the $F_{-I}$ alimony decree. ${ }^{112}$ The Mississippi court felt that it was required under the full faith and credit clause to establish the Nevada decree and to enforce it by equitable process, because an alimony decree is entitled to the extraordinary means of enforcement on account of its peculiar characteristics.

California, as we have seen, has on several occasions, pursued a similar policy. ${ }^{113}$ In Cousineau v. Cousineau, ${ }^{114}$ in addition ta back sums due under a California decree the defendant was ordered to make the payments in the future, the California decree as to the future installments was thus made the basis of an Oregon judgment. The court stated:

"If comity is the basis of the full faith and credit requirement, the decisions of our neighboring states (California and Washington), ought to be peculiarly persuasive, and we should endeavor to do as much for our neighbors as their courts stand prepared to do for the people of this state."115

In Shibley $v$. Shibley, ${ }^{116}$ the Washington court gave equitable enforcement to a California alimony decree. ${ }^{117}$ The Minnesota court followed suit in Ostrander $v$. Ostrander. ${ }^{118}$ The Connecticut court in German v. German ${ }^{119}$ enforced by contempt

212 Supra note roo.

I12 "It is our view that, on account of the character of a judgment for alimony, which rests, to some extent, upon public policy, in requiring a husband to support his wife and children, due to the sacred human relationship, and that they may not become public charges and derelicts, the decree for alimony, with the extraordinary power of enforcement by attachment and contempt proceedings, should be established and enforced by our equity court, which has full and sole jurisdiction of all matters of divorce and alimony; because to hold that a foreign judgment for alimony can be enforced in this state only by execution, the same as judgments at law, would be to impair or to deprive a foreign judgment for alimony of its inherent power of enforcement by attachment and contempt proceedings. Thus, as we view it, to so hold would be to disregard the 'full faith and credit' clause of the Federal law, which we interpret to mean that the judgment, with its peculiar right of enforcement, as one for alimony, should be established and enforced by the equity courts of our state in the same manner, and to the same extent, as it could have been enforced by our court if originally obtained in our state." Per Holden, J., at 737.

${ }^{113}$ Creager v. District Court, supra note 98; Cummings v. Cummings, supra note 97. In the Cummings case, it is true, because the husband had done everything he could to evade the New York alimony decree, the court had ample reason to feel that the wife's legal remedy was inadequate.

${ }^{114} 155$ Ore. 184,63 P. (2d) 897 (1936).

${ }^{115} \mathrm{Id}$. at 197, 63 P. (2d) 897 (1936), per Rossman, J.

${ }^{110}$ I8r Wash. I66, 42 P. (2d) 446 (r935).

117 "We adopt this procedure not on account of the rule of comity enjoined by the full faith and credit clause of the Federal constitution, but because, as a matter of public concern and equitable power, the enforcement in this state of such decrees for alimony and support money should not depend solely upon ordinary execution, but that the common practice in this state with respect to all the remedies for the enforcement of such decrees as if originally entered here should be followed and enforced." Per Mitchell, $\mathrm{J}$., at 170 .

${ }_{118} 190$ Minn. 547, 252 N. W. 449 (1934), discussed in (1934) I8 Mrch. L. REv. 589, (I934) IX N. Y. U. L. Q. REv. 634, (1934) I U. OF CFr. L. REv. 8II: The plaintiff had been awarded in South Dakota a divorce with alimony payable in installments. Her husband who had remarried wilfully refused to comply with the judgment. He had no property on which execution could be levied, and he persistently assigned his salary to his second wife to escape payment. The plaintiff obtained equitable relief in Minnesota to compel payment, the trial court having found that the wife had no adequate remedy at law. 
process alimony which had accrued under a New York decree, but refused to order specific performance of the judgment because the New York courts retain the power to modify future alimony.

Thus Fanchier $v$. Gammill has been followed: by a small but respectable body of authority. But the later decisions have not been placed on the requirement of the full faith and credit clause. This, it is submitted, is correct; a state is not obligated to afford any different relief to an $F-I$ alimony decree than it affords to any ordinary $F_{-I}$ money judgment. ${ }^{120}$ But it is not prevented from doing so if it so desires. And it must further be noted that in Ostrander v. Ostrander and German v. German equitable enforcement was given merely in regard to the accrued payments, while in the other cases the $F_{-I}$ decree was established so as to secure future sums as well.

Even prior to Fanchier v. Gammill, New York, by statutory enactment, had taken steps to give the wife a more effective remedy in regard to the $F_{-I}$ alimony decree. This was because of Lynde v. Lynde, ${ }^{121}$ which had denied to the wife in New York in the enforcement of the New Jersey alimony decree the statutory remedies of security, receivership, sequestration and contempt process. To remedy this situation $^{122}$ Sections 1772 and 1773 of the Code of Civil Procedure, now Civil Practice Act, Sections II $7 \mathrm{I}^{123}$ and II $72,{ }^{124}$ were amended in Ig04.

For Section II7I to apply, the alimony order must have been given in a suit for divorce on the ground of adultery, or in a suit for separation for one of the grounds specified in Civil Practice Act, Section $116{ }_{1}{ }^{125}$ and the action must be brought to

\footnotetext{
"Because of the nature of defendant's obligation and its origin, the enforcement of his duty is as much in need of attention of sovereign power as though he had remained in South Dakota. Transplantation of the parties from one state to another has not reduced the obligation to the ordinary category of 'a debt of record." "Per Stone, J., at 549.

110 Supra note 95.

${ }^{120}$ Lynde v. Lynde, supra note 45 ; Sistare v. Sistare, supra note 59.

121 4I App. Div. 280, 58 N. Y. Supp. 567 (r899), aff'd, x62 N. Y. 405,56 N. E. 979 (1900).

122 See Moore v. Moore, $x 43$ App. Div. 428, 43I, I28 N. Y. Supp. 7II (Igrr).

${ }^{123}$ Crv. PRAC. ACT, \$II7x: "Where a judgment rendered or an order made in this state for divorce or separation, or a judgment rendered in another state for divorce upon the ground of adultcry, or for separation or separate support for any of the causes specified in section eleven hundred and sixty-one of this act, upon which an action has been brought in this state and judgment rendered therein, requires a husband to provide . . . for the support of his wife, the court, in its discretion, may also direct him to give reasonable security ... f for the payment, from time to time, of the sums of money required for that purpose. If he fails to give the security, or to make any payment required by the terms of such judgment or order, whether he has or has not given security therefor, or to pay any sum of money for the cxpenses of the plaintiff, or her support and maintenance, ... the court may cause his personal property and the rents and profits of his real property to be sequestered, and may appoint a receiver thereof. . . " The italicized portions were added by N. Y. Laws I904, c. 328 .

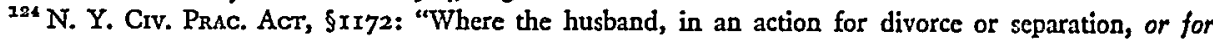
the enforcement in this state of a judgment for divorce or separation rendered in another state, makes default in paying any sum of money as required by the judgment or order directing the payment thercof, and it appears presumptively, to the satisfaction of the court, that payment cannot be enforced by means of the sequestration of his property, or by resorting to the security, . . . the court may, in its discretion, make an order requiring the husband to show cause ... why he should not be punished for his failure to make the payment; and thereupon proceedings must be taken to punish him, as prescribed in article nineteen of the judiciary law for the punishment of a contempt of court other than a criminal contempt. ..."The italicized portions were added in 1904 .

125 The grounds for a judicial separation are:

"(I) The cruel and inhuman treatment of the plaintiff by the defendant; (2) such conduct on the part of the defendant toward the plaintiff as may render it unsafe and improper for the latter to cohabit
} 
judgment in New York. These conditions the New York courts have rigidly enforced. ${ }^{126}$ If the divorce or separation was obtained on grounds other than those specified, Section II7I does not apply. ${ }^{127}$ Furthermore, the $F_{-I}$ decree must be reduced to judgment in New York. ${ }^{128}$ This is not done by a suit in equity even though equitable remedies are granted. ${ }^{129}$ If the court, under Section II7x, orders the husband to give security and he fails to do so, contempt proceedings are not available, sequestration being the limit of the statutory remedy. ${ }^{130}$ And in Boissevain v. Boissevain, ${ }^{131}$ it was held that Section $X I 7 \mathrm{I}$ is not applicable where the alimony decree was rendered in a foreign country (Holland, in this case) and not in a sister state.

Section $I I 72^{132}$ allows contempt proceedings to enforce the duty to pay. It is to be noted that this section does not in so many words contain the qualifications set forth in Section II $I$, that the $F-I$ divorce must be on the ground of adultery or the separation for one of grounds specified in Section II6r. Instead, it provides "for the enforcement in this state of a judgment for divorce or separation rendered in another state. . .." It has been held, and it is submitted, properly, that this section must be construed in the light of Section II7I, and that the two sections must therefore be read together. ${ }^{133}$ This would seem to have been the legislative intent-otherwise the anomaly would result of allowing the sanction of contempt, the most powerful of all alimony enforcement devices, in the case of all foreign decrees no matter what the ground, and of restricting the lesser sanctions of security and sequestration to decrees granted for the specified causes. Under this construction a foreign decree is placed on a par with a domestic decree. Again, under Section II72, in order to obtain the statutory relief, the F-r decree must be made a judgment of the New York court, $^{134}$ and a direction to pay granted in the judgment. Otherwise it will be construed as an ordinary law judgment. ${ }^{135}$

with the former; (3) the abandonment of the plaintiff by the defendant; (4) where the wife is plaintiff, the neglect or refusal of the defendant to provide for her."

${ }^{126}$ Beech v. Beech, 21I App. Div. 720, 208 N. Y. Supp. 98 (1925).

127 Beech v. Beech, supra note I26; Barber v. Warland, I39 Misc. 398, 247 N. Y. Supp. 455 (I930), divorce in Massachusetts on ground of desertion.

${ }^{128}$ Smith v. Smith, 249 App. Div, 660, 29I N. Y. Supp. 635 (1936).

${ }^{220}$ Beech v. Beech, supra note 126: "The law is well settled that an action can be brought in this state upon a judgment of this nature and a money judgment procured for alimony. Such a judgment when obtained can be enforced in accordance with our laws applicable thereto. The action, however, is not an equitable one, although the court may, in certain cases, under the provisions of section II7I of the Civil Practice Act, grant relief of an equitable nature." Per Merrell, J., at 72r. Accord: Barber v. Warland, supra note 127. Cf. Moore v. Moore, I43 App. Div. 428, I28 N. Y. Supp. 7xI (IgII), af'd, 208 N. Y. 97 , ror N. E. 7 XI (xgr3).

${ }^{130}$ Moore v. Moore, supra note 129.

${ }^{131} 252$ N. Y. 178, 169 N. E. 130 (1929), discussed in (1929) 29 CoL. L. REv. 522.

132 See note 124 , supra.

${ }^{188}$ Miller v. Miller, 219 App. Div. 6I, 219 N. Y. Supp. (1926), aff'd without opinion, 246 N. Y. 636, 159 N. E. 68I (1927): "We believe that sections II7I and II72 of the Civil Practice Act must be read together, and as so read under the construction given by this court in the Beech case to section Ix7I of the Civil Practice Act, the plaintiff herein having sued on a decree of a foreign court (Nevada) granting a divorce on the ground of cruelty, is limited under section II 72 of the Civil Practice Act to the recovery of a moncy judgment for the amount representing alimony for the support of himself and her children due and unpaid at the time specified in the order appealed from, which judgment can be enforced by execution." Per Burr, J., at 64-65.

134 Rohden v. Rohden, supra note 24 .

${ }^{106}$ Wemple v. Wemple, 219 App. Div. 24r, 219 N. Y. Supp. 638 (r937). 
Such is the state of the law concerning the enforcement in $F-2$ of an $F-I$ alimony decree. The rule of the great majority of courts, restricting the wife to an action of debt with the attendant legal execution, is open to serious objections. If the $F-I$ decree calls for periodic payments, suit can be brought in $F-2$ to recover only those installments which have accrued. If the husband continues his delinquent ways, a multiplicity of suits is inevitable. A long and, in some cases, a disastrous delay may result during which the wife and children may suffer untold hardship. The law side of the calendar often is badly overcrowded. Even after a judgment has been secured against the husband, execution must issue, and this involves the discovery of some property of the husband on which levy can successfully be had. If his assets are of a liquid character, they can easily be concealed, or the husband can flee the jurisdiction of the $F-2$ court, as he had formerly done in $F-r$. Furthermore, the law gives the wife no protection as to the future. Each time a payment falls due she must take legal action.

That the legal remedy is inadequate would seem self-evident. The ordinary $F-r$ money judgment calls for the reimbursement or compensation of the plaintiff. In this situation of little social consequence, the action of debt is fairly satisfactory. But an alimony decree providing for the vital necessities of wife and children presents an entirely different picture.

To say that alimony is a debt of record and enforceable only at law because the legal remedy is adequate and complete is entirely unrealistic. As before pointed out, ${ }^{136}$ the expression "debt of record" was adopted as a convenience in order to signify that an equity decree was a judgment capable of supporting an action of debt. As it has turned out the phrase has been unfortunate. Certainly alimony is much more. From the standpoint of society the husband's duty, strongly guarded as it is in $F-I$, with the full vigor of equitable enforcement, should not to such a large extent be dissolved by his crossing a state line. The legal attributes of alimony vary greatly from those of an ordinary money claim. Clearly the effective enforcement of the obligation to support should not be denied merely because it is labeled a "debt." It is no bar to the exercise of equitable jurisdiction that $F_{-I}$ alimony orders have long been dealt with in $F-2$ by legal action.

The courts of $F-2$ say again and again that the full faith and credit clause requires them to give effect to the $F_{-r}$ alimony decree. This means, according to them, the recognition of such a decree as a debt. Technically, under the theory of stare decisis, this is the law. But no decision of the Supreme Court has held that more cannot be done. It is, of course, true that the modes of enforcement available in $F-I$ are not, under the full faith and credit clause, binding in F-2. But $F-2$ is not asked to enforce the $F-I$ decree, but to establish it as a judgment of its own. The language in $M^{\prime} E l m o y l e$ v. Cohen ${ }^{137}$ that a judgment "can only be executed in the latter state $[F-2]$ as its laws may permit," in no way prevents an alimony judgment from becoming an equity decree in $F-2$. The problem is not one of full faith and credit, that is,

\footnotetext{
${ }^{130}$ Supra note 42.
}

${ }^{137}$ Supra note 23. 
not whether $F-2$ is compelled so to act, but whether on the grounds of comity adequate protection should be given the wife. It follows logically from this that the equitable remedies in $F_{-2}$, if there are any, should, therefore, be available to the wife. True, $F_{-2}$ should not give the alimony decree greater effect than it would have had in $F-I$. But the equitable relief in $F-2$ is a matter of discretion and in this way adequate protection will be given.

The alimony decree along with the effective enforcement thereof are important not only in $F-r$. Adequate remedies in $F-2$ can be provided only through enforcement in a court of equity with its vigorous sanctions, or by statute. Only in this way will an alimony order serve its function nationally.

The California, Washington, Oregon, Minnesota, Mississippi and Connecticut courts have of late indicated a willingness to look upon an $F-I$ alimony judgment as more than a mere debt of record. They have made the decree a judgment of their own courts. This forward step is fundamentally sound and is based on proper grounds of policy. New York has done much the same thing by means of legislation. Some such steps are necessary, even imperative, if an alimony decree is to have national consequences. 